\title{
INSTITUTIONAL QUALITY AND ECONOMIC GROWTH IN JORDAN: NEW EVIDENCE USING AN AUTOREGRESSIVE DISTRIBUTED LAG (ARDL) MODEL
}

\author{
QUSAI MOHAMMAD QASIM ALABED ${ }^{1,2}$, ZULKEFLY ABDUL KARIM*1, FATHIN FAIZAH \\ SAID $^{1}$ AND MOHD AZLAN SHAH ZAIDI ${ }^{1}$
}

${ }^{1}$ Center for Sustainable and Inclusive Development Studies (SID), Faculty of Economics and Management, Universiti Kebangsaan Malaysia, Bangi, Selangor, Malaysia. ${ }^{2}$ Al-Khalidiyah High School for Boys, Al-Mafraq, Jordan.

*Corresponding author: zak1972@ukm.edu.my

Submitted final draft: 5 June $2020 \quad$ Accepted: 14 June 2020

http://doi.org/10.46754/jssm.2021.04.015

\begin{abstract}
Since the 1990s, economists have looked for other significant determinants with a special focus on the quality of institutions to explain the heterogeneous trajectories of growth dynamics of countries around the world. In this regard, the current study provides the first empirical evidence in examining the relationship between institutional quality and economic growth in Jordan for the period of 1996-2017. The study uses an autoregressive distributed lag (ARDL) model as proposed by Pesaran et al. (2001). The empirical findings revealed that there is a co-integration (long-run co-movement) between economic growth and its determinants. Interestingly, there is a positive and significant relationship between institutional quality and economic growth in the long-run and shortrun. Moreover, the relationship between other explanatory variables such as investment, government size, inflation rate, and trade openness with economic growth is consistent with the standard economic theory. The policy implications from this study suggest that the Jordanian government should emphasize more on good institutional quality by improving all dimensions of institutional quality in sustaining their economic growth in the future.
\end{abstract}

Keywords: Economic growth, Jordan, Institutional quality, ARDL approach JEL classification: $\mathrm{C} 22, \mathrm{O} 43$.

\section{Introduction}

The relationship between institutional quality and economic growth has been debated by economists and researchers for decades, due to its impact on the determinants of economic growth. In the 1980s, economists such as Romer (1986) and Lucas (1988) introduced growth models which recognized that human capital and knowledge are key indicators. These models are known as endogenous growth models. By including human capital in a growth model, the power of explanatory power increases concerning variability in gross domestic product (GDP) per capita among countries but does not completely address the issue.

Romer (1990) pointed out that allocating more resources to innovation and efficiency in a growth model can improve a country's economic performance. According to Kacho and Dahmardeh (2017), human and physical capital, and technological changes cannot explain economic growth; hence, institutional quality has become an additional explanatory factor for dissimilar rates of economic growth between countries.

The first work to focus on the nexus between institutions and economic growth was that of North (1991), who considers institutions as one of the significant reasons behind the economic performance, along with other explanatory variables. Earlier empirical studies by (Mauro 1995; Barro, 1997 and Knack \& Keefer, 1995) found that institutions are important for both local and foreign investments. Zouhaier and Kefi (2006) note that good institutional quality provides an attractive environment to 
boost domestic and foreign economic agents' investments in human and physical resources, technology, research, and development.

In contrast, poor institutional quality can increase uncertainty, corruption, and transaction costs, thus discouraging investments. Moreover, high institutional quality could act as an economic growth driver by improving the efficiency of allocating resources (Dal Bo and Rossi, 2007), supporting choice freedom, and protecting property rights (Farhadi et al., 2015).

Furthermore, Yildirim and Gökalp (2016) found that variations in institutions among countries cause significant variations in education, productivity, and capital accumulation, which are reflected in income disparities among countries. Additionally, it has also been discussed that economic growth could be a reason for good institution quality. Valeriani and Peluso (2011) explored the bidirectional causality relationship between institutional quality and economic performance. The study concludes that institutional quality in developed countries is better than in developing ones. Also, the economic literature addresses the indirect role of institution indicators in affecting economic performance through trade openness (Hadhek \& Mrad, 2015) and foreign direct investments (Roy \& Roy, 2016).

\section{Regarding Worldwide Governance} Indicators (WGI) (2017), institutional quality is captured by six dimensions namely: political stability, rule of law, voice and accountability, regulatory quality, control of corruption, and government effectiveness. The above six dimensions are scaled from 0 to 100; a higher value indicates better institutional quality. Noticeably, high-income countries such as the United States (US), Singapore, Germany, and Qatar have high institutions index values of $84.6,88.95,89.53$, and 62.68 respectively in 2017. In contrast, low-middle income countries such as Egypt, Iran, and Nigeria have low institution index values of 22.62, 21.67, and 17.43 respectively in the same year.

Assaf (2014) pointed out that the Jordanian economy has experienced many external problems that have affected the economic environment, mostly caused by the neighboring countries. Making the government adopt economic reforms will help avoid the ramifications of these external challenges in terms of stability, both economically and politically.

Institutional quality is crucial for Jordan to flourish. It helps the economy to grow by protecting business activities via activation of the role of law, facilitating the process of investment, and so on. Mansoor and Quillin (2006), argued that institutions provide a suitable environment for investments, the security of the financial sector, and public services, which in turn enhance economic development.

According to North (1991), institutions represent formal and informal rules and constraints that affect a socio-economic interaction which helps in creating an inducement structure. These institutions boost economic efficiency by protecting property rights, decreasing risks, and transaction costs.

According to data reported by the World Bank for GDP per capita and Worldwide Governance Indicators for institutions index, Figure 1 shows the behavior of both institutional quality index and GDP per capita growth rate in the Jordanian economy. The average GDP per capita growth rate is 0.89 percent under the period of view, reached an ultimate height of 5.72 percent in 2004 and recorded the lowest rate of -2.88 percent in 2010 . In contrast, for institutional quality in Jordan, the average institution index was 51.24 during the period of study. Reaching the highest index of 55.73 in 1998 , meant the better institutional quality was in 1998 in Jordan's history. Besides, the record lowest institutions index of 47.41 in 2013, meant the worst of institutional quality. From 1996 to 2000 , it's notable that both of them increased in parallel. Then, from 2003 to 2010 the trend of both indicators declined. From 2012, the trends of both variables slow increased until 2017. This indicates to the co-relation between institution index and GDP per capita growth rates in Jordan. 
On the other hand, we can observe the opposite movement between the institution index and GDP per capita growth rates under the period of 2000-2003 as presented in Figure 1. The result can be justified by the fact the Jordanian economy was more vulnerable than the institutional environment to external shocks brought by a high degree of Jordanian trade openness in 2000 and the US invasion of Iraq in 2003 (International Monetary Fund, 2005).

As noted in Figure 1, the Jordan's economy recorded not only low growth rates of GDP per capita, but they were negative in some periods, especially from 2010 to 2017. Such countries could face many economic problems like high unemployment, the spread of poverty, social and financial weakness, and many others problems. Therefore, increasing the level of growth rates always has been at the top of the policymaker's agenda. However, the extent to which significant determinants of economic growth play an important role in Jordan represents the main issue for this study.

Jordan like any country, whether developed or developing, has a main objective to grow the economy fast and in a stable manner. The Jordanian economy is small and open to the world, with an upper-middle income level, the average growth rate of GDP per capita was 0.89 percent for the period under review. Jordan has limited natural and financial resources and continues to depend on tax revenues and investments to sustain its economy. Therefore, since 2009 Jordanian policymakers created a new set of structural and institutional reforms, specifically, an efficient tax system, inclusive governance, contract enforcement, flexible regulatory structure, improvements of the constitutional status and increase the transparency, guarantee fair competition and increase the sustainability of business to make more revenues and strengthen the economy (Central Bank of Jordan, 2010). This prompted the researchers to conduct the present study for Jordan, to explore the efficiency of institutional quality in promoting economic growth.

Therefore, this paper aims to explore the association between institutional quality and economic growth in Jordan for the period between 1996 and 2017. The contributions of the present study to the literature and policymakers can be organized in the following aspects. First, the present study provides information for Jordanian policymakers to achieve the desired growth rates by determining the most significant factors that affect economic growth. Second, the study presents new evidence regarding the relationship between institutions and economic growth, which could be the first work in the context of Jordan. No effort has yet been made to discover the effects of institutions along with other variables on growth in Jordan.

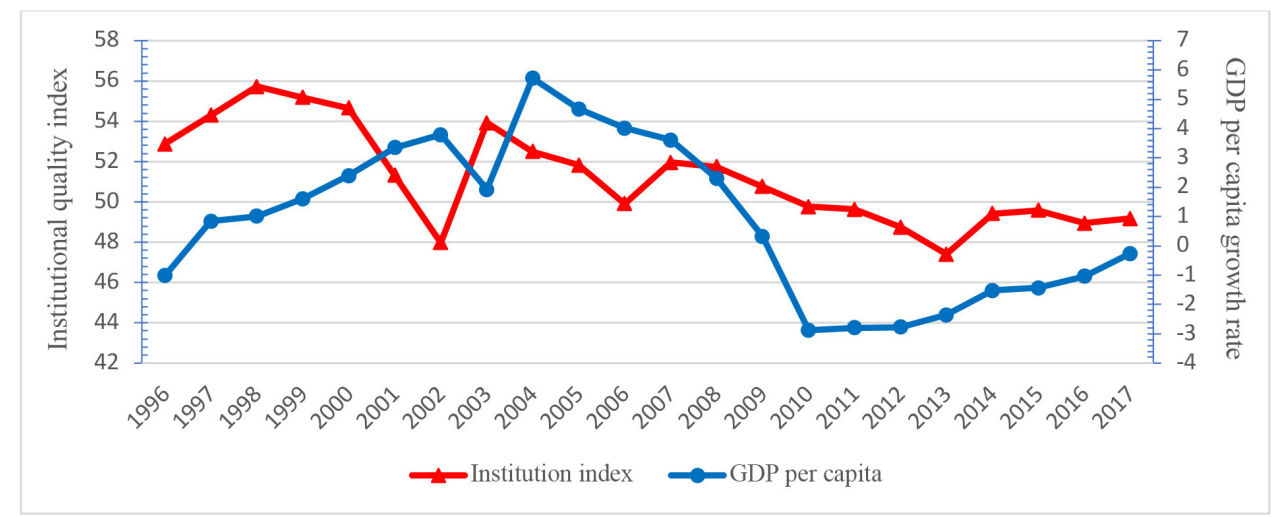

Figure 1: The GDP per capita growth rates and institutions index in Jordan (1996-2017) Source: Author, but underlying data from WB and WGI 
Therefore, this study extends previous empirical studies by (Assaf, 2014; Alrabadi \& Kharabsheh, 2016; Al-khawaldeh \& Alqudah, 2018; Obeid \& Awad, 2018; Al-Tamimi \& Jaradat, 2019; Al-Sharif \& Bino, 2019), by integrating the roles of institutions in growth theories. To do this, the autoregressive distributed lag (ARDL) approach of PesaFran et al. (2001) has been employed.

The significance of the study is to investigate the role of institutional quality on economic growth in Jordan, this issue has not been discovered for the case of Jordan. This may provide further information for policymakers to understand the significant determinants of economic growth.

This study has been organized into five sections. Section 1 includes the introduction, while section 2 presents a review of the theoretical and empirical literature. Methodology and data used are elucidated in section 3, while the findings of this study are explained in section 4 . The summary and conclusions in section 5 .

\section{Literature Review}

\section{Theoretical Background}

The idea that high institutional quality represents a vital aspect of economic performance in any country is not new, many empirical studies found the proof of that. The institutional quality-economic growth nexus has been well established on the theoretical side. According to North (1991), institutional quality is the rule of the game in the community. Institutions that shape the motivational structure of the community could increase economic activity. Thus, institutional barriers represent the key obstacle for poor countries to enhance their economic performance. Moreover, he argued that institutions stimulate the growth of countries because they facilitate the process of innovations and increase productivity because of the reduction in transaction costs.

Moreover, Hall and Jones (1999) found that the total productivity factor in any country is motivated by its institutional quality. Well- developed and efficient institutions ensure that labour will be used properly in productive activities, without wasting them for unwanted purposes. Bernard and Jones (1996) outline that good institutions enable countries to introduce new technologies necessary for improving the development of the country.

To formulate the above discussion in a theoretical framework, the present study uses the endogenous growth model. Law and Bany-Ariffin (2008) clarified the influences of institutions on economic growth using the production function of Cobb-Douglas, which refers to the total output in each country. Therefore, the production function can be characterised by the following equation:

$$
\mathrm{Y}=\mathrm{K}^{\alpha}(\mathrm{AL})^{1-\alpha}
$$

where $Y$ refers to aggregate output, a stock of labour represented by $L, K$ denotes the physical capital stock, and $A$ characterizes a labour productivity factor which is a proxy of technology progress. It is supposed that $a<1$, which means that there is reducing returns in capital stock. Labour and labour productivity is supposed to change due to the following equations:

$$
\begin{gathered}
\mathrm{L}=\mathrm{L}_{0} \mathrm{e}^{\mathrm{n}} \\
\mathrm{A}=\mathrm{A}_{0} \mathrm{e}^{\mathrm{g}+\mathrm{P} \theta}
\end{gathered}
$$

The subscript $n$ refers to the exogenous rate of labour, $g$ represents exogenous rate in the level of technical efficiency, $P$ denotes the vector of institutional quality indicators and any further elements which may affect technological progress, $\theta$ refers to a vector of coefficients associated with these elements. Therefore, labour productivity factors which mean the level of technology $A$ is based not only on technological developments, decided by $g$, but also depends on the quality of institutions, as efficient and uncorrupted institutions' labour forces can be employed for productive functions, rather than remaining unused in economic activities (North, 1991). 
Affording to Law and Bany-Ariffin (2008), output growth per worker is a constant rate $g$ in the steady-state (exogenous factors of the efficiency growth rate $A$ ). Therefore, output per effective worker can be gotten directly from the following equation:

$$
\frac{\mathrm{Y}}{\mathrm{AL}}=(\mathrm{K})^{\alpha}
$$

Applying equation (3), then we reach:

$$
\ln \mathrm{Y}=\ln \mathrm{A}_{0}+(1-\alpha) \mathrm{g}+(1-\alpha) \mathrm{P} \theta+\alpha \ln \mathrm{K}
$$

Equation (7) explains the growth of productivity of labour or output per worker as a function of institutional quality factors, which can change during a given period, and with the level of
On the other hand, in terms of a raw worker, output changes due to:

$$
\frac{\mathrm{Y}}{\mathrm{L}}=\mathrm{A}(\mathrm{K})^{\alpha}
$$

By taking the logs for each side of the above equation, we get:

$$
\ln Y=\ln A+\alpha \ln K
$$

$$
\ln Y=\ln A_{0}+(1-\alpha) g+(1-\alpha) P \theta+\alpha \ln K+u
$$

where $P$ is a variable referring to the institutional quality and $u$ is an error term.

Acemoglu and Robinson (2010) pointed out that institutional quality represents a crucial element in determining the level of growth and development variations among countries. Therefore, institutional quality has taking its place by economists and researchers, since traditional economic growth models cannot explain the variations of growth between countries, to decide the most significant determinants of economic growth.

\section{Empirical Review}

Studying the association between institutions and economic growth has been taking place with researchers and policymakers in both developing and developed nations worldwide. A study by Liu et al. (2018) found that quality of governance positively affects economic growth, where the high quality of governance may bring a high-speed economic growth effect by diminishing marginal returns. A similar paper by Karimi and Daiari (2018) studied the effects of institution dimensions on economic development. They showed a significant physical capital or the exogenous growth rate of output. By adding an error term, the functional linear form of the above equation will be as follow:

and positive relationship between these two indicators in certain Association of Southeast Asian Countries (Asean) countries for the period between 1996 and 2014.

Moreover, Kacho and Dahmardeh (2017) used annual frequency data to explore the influence of institutional quality on growth in The Organisation for Economic Co-operation and Development (OECD) nations. The outcomes confirm the positive influence of institutional indicators on economic development. These results bolster the substantial role played by institutional quality in achieving high economic growth rates by increasing the efficiency of resource allocation.

Investigating a panel of 28 European nations during the period 1996 to 2014, Siyakiya (2017) employed a system generalized method of moments (GMM) approach. He exposed a positive linkage between institutions and economic performance and revealed that institutional quality in developed countries was higher than in developing countries. Yildirim and Gökalp (2016) conducted a study for 38 developing nations under the period of 20002011. The findings showed that institutional 
indicators such as rules on trade barriers, the sharing in the banking system by the private sector, integrity of the law, and constraints of foreign investment have positively influenced economic growth.

Judicial independence, civil freedom, collective bargaining, subsidies and transfers, military tutelage, and black-market exchange rate have a negative influence on economic performance. Similarly, in developing nations specifically in the case of Middle East and North Africa (MENA) countries, Roy and Roy (2016) clarified the impact of institutions on the economic performance during the period from 2006 to 2012, the outcomes confirmed the positive linkages between these two variables.

Nawaz et al. (2014) demonstrated the effectiveness of an institution's quality in prompting economic performance in certain Asian countries from 1996 to 2012. Based on GMM approach, findings of this study reveal that good institutional quality influence positively on growth rates, the study concluded that institutions of developed nations are more effective than those of developing nations in Asia. Focusing on property rights and security is an important indicator of the institutions needed to enhance growth in MENA countries.

Becherair (2014) showed that property rights and security are the most significant elements of institutional quality used in expounding the variations of growth rates of 15 MENA area countries during the 1995 to 2012 period.

Furthermore, institutional quality has an effective role in the relationship between economic growth and the other macroeconomic variables. Brahim and Rachdi (2014) investigated the influence of institutions in the relationship among foreign direct investment (FDI) and growth rate. They found a non-linear relationship between FDI and growth rate.

Additionally, this relationship depends on the institutional quality in these countries. Empirical results based on a panel smooth transition regression approach in 19 MENA area countries from 1984 to 2011 confirmed that countries with good institutional quality improve the advantage of FDI effects in economic performance. Additionally, determining the causality relationship between institutional quality and economic development is important to help policymakers to design their economic policies.

Moreover, a study by Bass (2019) based on Granger causality explored the unidirectional causality linkage running from institutions to economic development in the Russian Federation for the period 1996-2017. This indicates the significant role of institutions in terms of enhancing the overall economic activities.

A similar study by Ologunla et al. (2014) attempted to examine the causality link between economic freedom index and growth rate in the Nigerian economy, covering the period of 1986-2012. The outcomes of Granger causality revealed that a high freedom index caused higher growth rates. Moreover, in the context of the MENA region, Gazdar and Cherif (2014) found that institutions caused economic growth.

More recently, in a set of 45 Sub-Saharan African nations. Doan (2019) examined the institutional quality effects on economic growth for the period 1980-2013. His study confirmed a positive nexus between these two variables.

Investigating the determents of economic growth has been the concern of researchers and policymakers in Jordan. Many empirical studies have been conducted, such as those by (AbdulKhaliq et al., 2013; Assaf, 2014; Alrabadi \& Kharabsheh, 2016; Al-khawaldeh \& Al-qudah, 2018; Obeid \& Awad, 2018; Al-Tamimi \& Jaradat, 2019; Al-Sharif \& Bino, 2019).

Most of the above studies demonstrate the influence of macroeconomic factors on economic performance. None of them tried to investigate the effects of institutions on economic growth in the case of the Jordanian economy.

Given this background, the present study fills the gaps of literature in the following aspects. First, this study extends the above studies by 
investigating the effects of institutional quality on economic performance in Jordan from 1996 to 2017.

Second, this study improves upon previous studies by examining all dimensions of institutions as introduced by Worldwide Governance Indicators (WGI), including political stability, rule of law, voice and accountability, regulatory quality, control of corruption, and government effectiveness.

Therefore, an institutional quality indicator for the present study is gotten by averaging the above six dimensions. A high index value indicates good institutional quality and vice versa.

\section{Methodology and Data Used}

\section{Data Description}

Our study examined the Jordanian economy based on annual frequency data covering the period 1996-2017. The time series is chosen due to the data availability of our variables. The study variables include the growth rate of GDP per capita, investment, trade openness, government size, and inflation rate.

Gross fixed capital formation serves as an indicator of investment, while government current expenditure represents government size. All these above variables were obtained from the World Development Indicators (WDI) database of the World Bank.
Furthermore, the institutional quality variable used in the present study is gotten by averaging the six dimensions of institutions mentioned earlier as published by WGI. These dimensions range from 0 to 100 , with higher values indicating better institutional quality. The definitions of variables used, and the source of data are reported in Appendix A.

Based on the descriptive statistics shown in Appendix B, we can see the main measurements of study variables and consist number of observations, mean, standard deviation, minimum, and maximum. Therefore, the average growth rate of GDP per capita is 0.89 percent and ranges from -2.88 to 5.72 . Additionally, the average index of institutional quality is 51.24 and ranges from 47.41 to 55.73 .

Furthermore, the correlation matrix in Appendix C displays a positive correlation between institutional quality, investment, government size, and trade openness with economic growth, while the inflation rate correlated negatively with economic growth, as predicted and discussed in economic growth theories.

\section{Model Specification and Estimation Method}

Numerous empirical studies have investigated the effects of institutions on economic growth. Therefore, to examine the influences of institutional quality on economic growth in Jordan, the present paper follows the studies of (Nawaz et al., 2014; Siyakiya, 2017). Thus, our model is specified as:

$$
G R O W T H_{t}=\beta_{0}+\beta_{1} G F C F_{t}+\beta_{2} G X_{t}+\beta_{3} I N F_{t}+\beta_{4} T O_{t}+\beta_{5} \operatorname{lnINS_{t}}+\varepsilon_{t}
$$

Where GROWTH refers to GDP per capita growth rate, GX is the share of total government expenditures as a percentage of GDP, GFCF is gross fixed capital formation as a share of GDP used as a proxy of investment, TO is trade openness (trade volume (export plus import) as a percentage of GDP), INF denotes inflation rate, INS is an institutional index, is the error term, and $t=1 \ldots \ldots, 22$ represent time. Therefore, to get a better understanding of the nexus between each independent variable with the dependent variable, autoregressive distributed lags ARDL technique of Pesaran et al. (2001) will be applied.

According to the theoretical and empirical literature, the impact of investment is expected to be positive, as an increase of investment leads to boost aggregate demand, which in turn, increases the rates of growth (Barro, 1991). The government expenditure would be positive 
as expected, more government spending (both capital and current) raises domestic demand for goods and services then increase economic growth (Keynes, 1936).

The impact of inflation could be positive or negative, economic theories have argued that inflation has a positive impact on growth (Philips, 1958), while others found that inflation harms growth through the reduction in productivity and investments because of uncertainty in the economy (Fischer, 1993). The trade openness would be positive as expected, it increases the aggregate demand and enhances the competition in the international market.

Finally, the impact of institutional quality is expected to be positive, it increases productivity through enhancing the incentive structure, and reduce the costs of doing business (North, 1991).

The autoregressive distributed lag (ARDL) technique for co-integration, also known as cointegration bounds test, this type of econometric analysis has certain advantages compared to other co-integration methods. The ARDL model is a single-equation technique and requires the estimation of a fairly small number of parameters, this technique is more efficient, particularly with small samples of data (Alexiou et al., 2014).

Moreover, Pesaran et al. (2001) pointed out the advantages of applying the ARDL method as compared with other approaches, as it does not require the set of variables used to be integrated with a similar order, i.e., there is no problem when the variables are stationary at the level or first difference. Besides, the ARDL technique is suitable for any size sample, while other approaches do not work with small samples. Moreover, the ARDL method presents unbiased estimations of the long-run model even if some explanatory variables are endogenous (Sallam, 2016). Thus, the ARDL (p, q, r, s, t, u) model employed in the present study is formulated as follows:

$$
\begin{aligned}
\text { GROWTH }_{\mathrm{t}} & =\alpha_{0}+\sum_{\mathrm{j}=1}^{\mathrm{p}} \delta_{1} \mathrm{GROWTH}_{\mathrm{t}-\mathrm{j}}+\sum_{\mathrm{j}=0}^{\mathrm{q}} \delta_{2} \mathrm{GFCF}_{\mathrm{t}-\mathrm{j}}+\sum_{\mathrm{j}=0}^{\mathrm{r}} \delta_{3} \mathrm{GX}_{\mathrm{t}-\mathrm{j}}+\sum_{\mathrm{j}=0}^{\mathrm{s}} \delta_{4} \mathrm{INF}_{\mathrm{t}-\mathrm{j}} \\
& +\sum_{\mathrm{j}=0}^{\mathrm{t}} \delta_{5} \mathrm{TO}_{\mathrm{t}-\mathrm{j}}+\sum_{\mathrm{j}=0}^{\mathrm{s}} \delta_{6} \operatorname{lnINS}_{\mathrm{t}-\mathrm{j}}+\varepsilon_{\mathrm{t}}
\end{aligned}
$$

Where is the operator of the first difference, refers to constant, 's refers to coefficients of the long-run, 's are coefficients of the short-run, and denotes error term. Therefore, depending on the joint F-statistic, the ARDL bounds test is applied to decide the presence of a long-run association between variables. The null hypothesis is no co-integration between variables determined as $\mathrm{H}_{0}:==\ldots \ldots==0$ as verified compared to the alternative, which is $\mathrm{H}_{1}: \neq \neq \ldots \neq \neq \neq 0$. Therefore, if the value of F-statistic is greater than the values of upper bounds, the null hypothesis is rejected, which means there is co-integration between the variables. In contrast to this, if the value of F-statistic less than the values of lower bounds, the null hypothesis is accepted, which means that there is no co-integration between the variables. But if the F-statistic value is between the lower bounds and upper bounds, this means that the test of co-integration is inclusive (Ayuba and Mohd Khan, 2019).

We found evidence for the existence of a long-run relationship; hence, the long-run ARDL $(\mathrm{p}, \mathrm{q}, \mathrm{r}, \mathrm{s}, \mathrm{t}, \mathrm{u})$ model is expressed as follows:

$$
\begin{aligned}
\text { GROWTH }_{t} & =\alpha_{0}+\sum_{j=1}^{\mathrm{p}} \delta_{1} \mathrm{GROWTH}_{\mathrm{t}-\mathrm{j}}+\sum_{\mathrm{j}=0}^{\mathrm{q}} \delta_{2} \mathrm{GFCF}_{\mathrm{t}-\mathrm{j}}+\sum_{\mathrm{j}=0}^{\mathrm{r}} \delta_{3} \mathrm{GX}_{\mathrm{t}-\mathrm{j}}+\sum_{\mathrm{j}=0}^{\mathrm{s}} \delta_{4} \mathrm{INF}_{\mathrm{t}-\mathrm{j}} \\
& +\sum_{\mathrm{j}=0}^{\mathrm{t}} \delta_{5} \mathrm{TO}_{\mathrm{t}-\mathrm{j}}+\sum_{\mathrm{j}=0}^{\mathrm{u}} \delta_{6} \operatorname{lnINS}_{\mathrm{t}-\mathrm{j}}+\varepsilon_{\mathrm{t}}
\end{aligned}
$$


Finally, after confirming the presence of relationships among the variables in terms of long-run, the error correction model was applied, to get the coefficients short-run, whereas
$\mathrm{ECM}_{(\mathrm{t}-1)}$ refers to the correction mechanism of disequilibrium in our model, also known the speed of adjustment or feedback effect (Sallam, 2016). Therefore, the short-run ARDL (p, q, r, s, $t, u)$ model form is expressed as follows:

$$
\begin{array}{r}
\Delta \text { GROWTH }_{\mathrm{t}}=\alpha_{0}+\sum_{\mathrm{j}=1}^{\mathrm{p}} \beta_{1} \Delta \mathrm{GROWTH}_{\mathrm{t}-\mathrm{j}}+\sum_{\mathrm{j}=0}^{\mathrm{q}} \beta_{2} \Delta \mathrm{GFCF}_{\mathrm{t}-\mathrm{j}}+\sum_{\mathrm{j}=0}^{\mathrm{r}} \beta_{3} \Delta \mathrm{GX}_{\mathrm{t}-\mathrm{j}} \\
+\sum_{\mathrm{j}=0}^{\mathrm{s}} \beta_{4} \Delta \mathrm{INF}_{\mathrm{t}-\mathrm{j}}+\sum_{\mathrm{j}=0}^{\mathrm{t}} \beta_{5} \Delta \mathrm{TO}_{\mathrm{t}-\mathrm{j}}+\sum_{\mathrm{j}=0}^{\mathrm{u}} \beta_{6} \Delta \operatorname{lnINS}_{\mathrm{t}-\mathrm{j}}+\varphi \mathrm{ECM}_{\mathrm{t}-1}+\varepsilon_{\mathrm{t}}
\end{array}
$$

Where $\varphi$ represents the speed of adjustment of error correction residual, resulting from the estimates of the ARDL model. Moreover, to determine if the ARDL model fits, several diagnostic tests were employed, such as serial correlation, normal distribution, and heteroscedasticity. CUSUM and CUSUMQ were employed to decide the stability of our model.

\section{Empirical Results}

The ARDL model requires testing the integration of our variables. The present study examines the presence of unit roots and decides the level of integration for the study variables. Both Augmented Dickey-Fuller (ADF) and Phillips and Perron (PP) were applied. The findings of unit roots are reported in Table 1. They show that in the levels of time series variables, only the inflation rate is stationary for both tests. Moreover, the results of both tests reveal that all of the study's variables are stationary and strongly significant in the first difference.

Before estimating our ARDL model, first, the co-integration relationship between dependent and independent variables must be investigated by applying the bounds test for cointegration. Table 2 present the results of the bounds test for the ARDL model.

The results indicate the presence of a longrun relationship between economic growth and our explanatory variables. Noteworthy, the

\begin{tabular}{|c|c|c|c|c|}
\hline \multirow[t]{2}{*}{ Variable } & \multicolumn{2}{|c|}{ ADF-test } & \multicolumn{2}{|c|}{ PP-test } \\
\hline & At I(0) & At I(1) & At I $\mathbf{I}(0)$ & At I(1) \\
\hline GROWTH & $\begin{array}{l}-1.299 \\
(0.629)\end{array}$ & $\begin{array}{c}-4.281 \\
(0.000) * * *\end{array}$ & $\begin{array}{l}-1.456 \\
(0.555)\end{array}$ & $\begin{array}{c}-4.287 \\
(0.000) * * *\end{array}$ \\
\hline GFCF & $\begin{array}{l}-1.811 \\
(0.375)\end{array}$ & $\begin{array}{c}-4.191 \\
(0.000) * * *\end{array}$ & $\begin{array}{l}-1.980 \\
(0.295)\end{array}$ & $\begin{array}{c}-4.190 \\
(0.000) * * *\end{array}$ \\
\hline GX & $\begin{array}{c}-0.835 \\
(0.808)\end{array}$ & $\begin{array}{c}-8.174 \\
(0.000) * * *\end{array}$ & $\begin{array}{l}-0.402 \\
(0.909)\end{array}$ & $\begin{array}{c}-12.184 \\
(0.000) * * *\end{array}$ \\
\hline INF & $\begin{array}{c}-4.293 \\
(0.000) * * *\end{array}$ & $\begin{array}{c}-8.513 \\
(0.000) * * *\end{array}$ & $\begin{array}{c}-4.316 \\
(0.000) * * *\end{array}$ & $\begin{array}{c}-9.481 \\
(0.000)\end{array}$ \\
\hline TO & $\begin{array}{l}-0.988 \\
(0.757)\end{array}$ & $\begin{array}{c}-3.475 \\
(0.008) * * *\end{array}$ & $\begin{array}{l}-1.307 \\
(0.626)\end{array}$ & $\begin{array}{c}-3.428 \\
(0.001) * * *\end{array}$ \\
\hline INS & $\begin{array}{l}-1.928 \\
(0.319)\end{array}$ & $\begin{array}{c}-5.332 \\
(0.000) * * *\end{array}$ & $\begin{array}{l}-1.803 \\
(0.379)\end{array}$ & $\begin{array}{c}-5.750 \\
(0.000) * * *\end{array}$ \\
\hline
\end{tabular}

Table 1: Test of a unit root

Note: $1 \%, 5 \%$ and $10 \%$ significant level represented by $*, * *, * * *$ respectively. The value in the parenthesis is P-value. 
Table 2: ARDL co-integration bounds test

\begin{tabular}{ccccc}
\hline Regression function & F-statistic & Sig. level & Lower bound & Upper bound \\
\hline GROWTH f(GFCF, GE, INF, TO, INS) & 10.779 & $10 \%$ & 2.26 & 3.35 \\
& & $5 \%$ & 2.62 & 3.79 \\
& & $2.5 \%$ & 2.96 & 4.18 \\
& & $1 \%$ & 3.41 & 4.68 \\
\hline
\end{tabular}

calculated value of F-statistic is larger than the upper bound even at $1 \%$ significance; thus, the null hypothesis is excluded, which means that there is co-integration between the variables. Therefore, estimating our model using the ARDL approach is permitted.

Table 3 includes the results of diagnostic tests related to the ARDL model, including $\mathrm{ARCH}$ for heteroscedasticity, Jarque-Bera for normality, and Breusch-Godfrey for serial correlation. The results of these tests provide evidence of the null hypotheses of all diagnostic tests, as the $P$-value of each test is bigger than 0.05 . Thus, there are absences of non-normality, no heteroscedasticity, and no serial correlation for all estimated regressions.

The empirical findings in Table 4 include estimations of the long and short-run coefficients of the ARDL model. The optimal lag length is $\operatorname{ARDL}(1,1,0,0,1,1)$, as decided automatically using Akaike Information Criterion (AIC). Therefore, the long-run coefficients show a positive and significant relationship between the quality of institutions and economic growth, this means improving institutional quality by 1 point may increase economic growth by 0.074 percent. North (1991) argued that good institutions increase the efficiency of the production process and reduce the costs of doing business. This result is consistent with many empirical studies of (Nawaz et al., 2014; Siyakiya, 2017; Kacho and Dahmardeh, 2017; Liu et al., 2018; Doan, 2019).

Moreover, the results revealed that investment has a positive and significant effect on economic growth, implying that a 1 percent increase investment leads to an increase in economic growth by 0.066 percent. Investment recognized as an important element of aggregate demand, therefore; increased investment leads to increase aggregate demand, then increases growth rates (Barro, 1991). A study of (Epaphra \& Massawe, 2016; Maaida, et al., 2012, and Haque, 2012), also revealed the same result. Besides, the study found that government expenditure has a positive and statistically significant effect on economic growth, this means a 1 percent increase in government expenditure leads to 0.494 percent increase in economic growth. The Keynesian theory believes that government spending is the main driver for growth. This finding in line with many empirical studies such as (Oyinlola and Akinnibosun, 2013; Adewara \& Oloni, 2012, Afzal \& Abbas, 2012).

Trade openness found to be positive and significant with a value of 0.112 , implying that a 1 percent increase in trade openness leads to increase economic growth by 0.112 percent. Romer (1990), international trade supports the speed up of growth, under the endogenous growth model, the way of how trade affects

Table 3: Diagnostic tests

\begin{tabular}{lll}
\hline \multicolumn{1}{c}{ Test } & Statistic value & Probability \\
\hline Normality test (Jarque-Bera) & 1.287 & 0.525 \\
Serial correlation test (Breusch-Godfrey) & 0.609 & 0.565 \\
Heteroscedasticity test (ARCH) & 0.278 & 0.604 \\
\hline
\end{tabular}


growth is increasing the demand of goods and services and enhance productivity via technology transmission. This finding is consistent with studies of (Keho, 2017; Fenira, 2015).

Additionally, the results revealed that inflation has a negative and insignificant effect on economic growth with a value of 0.207 . Fischer (1993) discussed that increasing the price level creates an uncertainty in the economy, this may reduce productivity and investments then harms economic growth. This result in line with many empirical studies such as (Baharumshah et al., 2016; Odhiambo, 2012).

On the other hand, the short-run coefficients, the outcomes provide evidence of the negative and significant effects of the inflation rate on economic growth, with a coefficient value of 0.851 , indicating that a 1 percent increase in inflation rate leads to about 0.851 decrease of economic growth. Additionally, the outcomes revealed a positive and statistically significant association between government size and institutional quality with growth rate, whereas a 1percent increase in government size increased economic growth by approximately 0.222 while improving institutional quality by 1 point and increasing economic growth by 0.771 .

Furthermore, the coefficient of error correction term is negative and significant with a value of 0.577 , confirming the long-run relationship exists among economic growth and the rest of the variables. This indicates that if economic growth deviates from the longrun equilibrium, all independent variables of our model are correct at around 0.577 of disequilibrium in the same period.

Moreover, the coefficient of adjusted $\mathrm{R}$-squared explains the total variations in the dependent variable. In our model, about 0.890 of the differences in economic growth are clarified by our explanatory variables.

Finally, it is important to investigate the stability of the ARDL model used in the present study. In this regard, both cumulative sum

Table 4: The coefficients of a long and short run of the ARDL model

\begin{tabular}{llcc}
\hline \multicolumn{1}{c}{ Variable } & Coefficient & Standard Error & P-value \\
\hline Long-run results & & & \\
GFCF & $0.066^{*}$ & 0.136 & 0.064 \\
GE & $0.494^{* *}$ & 0.286 & 0.021 \\
INF & -0.207 & 0.137 & 0.160 \\
TO & $0.112^{* * *}$ & 0.031 & 0.004 \\
INS & $0.074^{* *}$ & 0.156 & 0.046 \\
Constant & $-1.310^{* * *}$ & -2.330 & 0.005 \\
Short-run results & & & \\
$\Delta$ GFCF & -0.717 & 0.163 & 0.170 \\
$\Delta$ GE & $0.222^{* *}$ & 0.049 & 0.041 \\
$\Delta \mathrm{INF}$ & $-0.851^{* * *}$ & 0.255 & 0.008 \\
$\Delta \mathrm{TO}$ & -0.113 & 0.197 & 0.582 \\
$\Delta \mathrm{INS}$ & $0.711^{* *}$ & 0.288 & 0.036 \\
ECT t & $-0.577^{* * *}$ & 0.412 & 0.003 \\
Log-likelihood & -20.496 & & \\
R-squared & 0.939 & & \\
Adjusted R-squared & 0.890 & & \\
\hline
\end{tabular}

Note: $1 \%, 5 \%$ and $10 \%$ significant level represented by $*, * *, * * *$ respectively. 


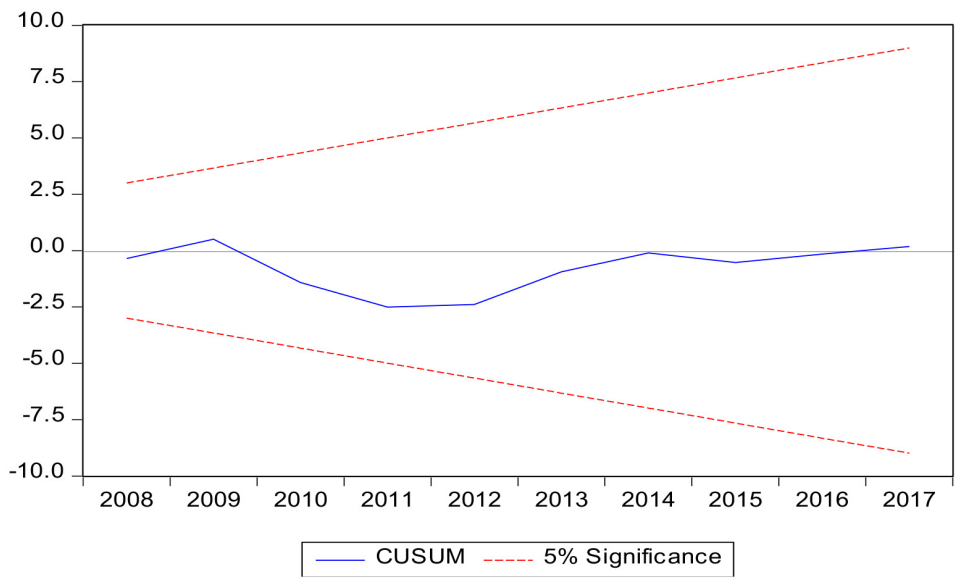

Figure 2: CUSUM Statistics

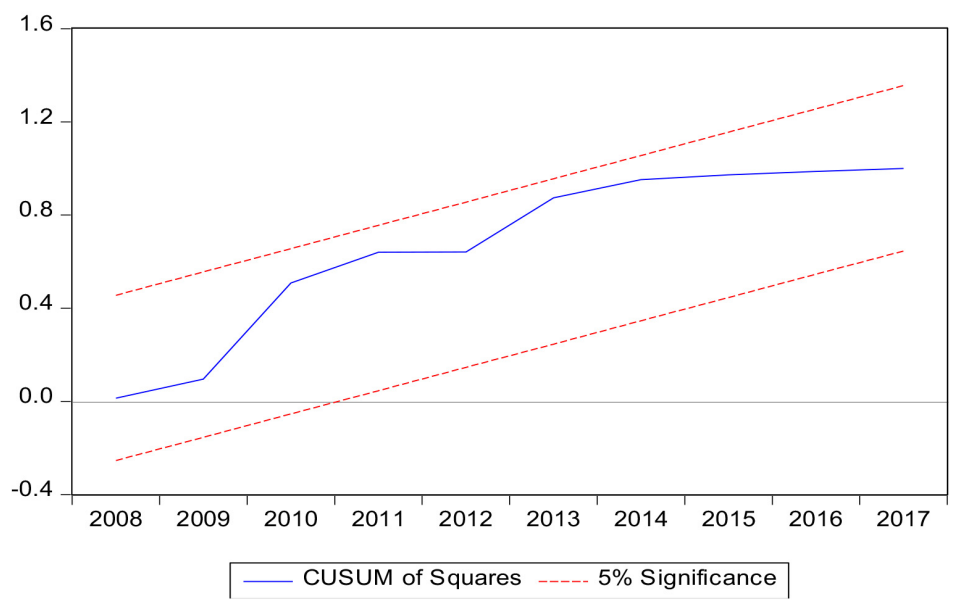

Figure 3: CUSUMQ Statistics

of squares (CUSUMQ) and cumulative sum (CUSUM) are employed. As shown in Figure 2 and Figure 3, the findings of these tests fail to exclude the null hypothesis with the significance of 5 percent, we can notice that the plot of both tests fallen between the critical bounds. Therefore, these statistical tests support the stability of the model of the present study.

\section{Conclusion}

A high rate of economic growth is the main objective of any economy worldwide. Hence, the determinants of economic growth have been a subject debate of economists and researchers for decades. Recently, economists and researchers have been considering the sources of economic growth to clarify reasons for the differences in GDP per capita among countries beyond traditional growth theories.

Therefore, given the importance of good institutional quality as discussed earlier, the present study tries to extend the determinants of economic growth by exploring the relationship between institutional quality and economic growth in Jordan during the 1996-2017 period, using the autoregressive distributed lags ARDL approach of Pesaran et al. (2001).

The empirical results indicate that institutional quality affects positively and significantly on economic growth in both the 
short-run and long-run. Thus, institutional quality is an essential determinant of growth in Jordan. Moreover, the empirical findings reveal the positive and significant effects of investments, government size, and trade openness on economic growth, and negative but statistically insignificant effects of inflation on economic growth. These findings are in line with many empirical studies, also with the economic theory predictions.

Therefore, the policy implications of this study suggest that government leaders and policymakers should improve all dimensions of institutions. Specifically, eliminating corruption, enhance government performance, maintaining country stability, activate the role of laws, increase the quality of regulatory and accountable bureaucracy to reform institutional policies to grow up the growth rates.

Hence, enhancing the institution's dimensions should be a vital guideline for policymakers in Jordan. On the other hand, policymakers should implement effective monetary and fiscal policies in a way to increase investments and reduce inflation rates via lowering interest rates and expanding in government expenditure, specifically capital expenditure.

\section{Acknowledgements}

The authors would like to thank Universiti Malaysia Terengganu for providing financial assistance to complete this study.

\section{References}

Abdul-Khaliq, S., Soufan, T., \& Abu Shihab, R. (2013). Intensive economic growth in Jordan during 1978-2010. International Journal of Business and Management, 8(12), 143-154.

Acemoglu, D., \& Robinson, J. (2010). The role of institutions in growth and development. Review of Economics and Institutions, 1(2).

Adewara, S. O., \& Oloni, E. F. (2012). Composition of public expenditure and economic growth in Nigeria. Journal of Emerging Trends in Economics and Management Sciences, 3(4), 403-407.

Afzal, M., \& Abbas, Q. (2012). Wagner's law in Pakistan: Another look. Journal of Economics and International Finance, 2(1), 12-19.

Alexiou, C., Tsaliki, P., \& Osman, H. R. (2014). Institutional quality and economic growth: Empirical evidence from the Sudanese economy. Economic Annals, 59(203), 119137.

Al-Khawaldeh, M., \& Al-Qudah, A. (2018). The effect of energy consumption on economic growth in Jordan. International Journal of Academic Research in Accounting and Management Sciences, 8(2), 170-177.

Alrabadi, D. W., \& Kharabsheh, B. A. (2016). Financial deepening and economic growth: The case of Jordan. Journal of Accounting and Finance, 16(6), 158-166.

Al-Sharif, B., \& Bino, A. (2019). The role of government capital expenditures in economic growth in Jordan. International Journal of Business and Economics Research, 8(2), 69-77.

Al-Tamimi, K. A., \& Jaradat, M. S. (2019). Impact of external debt on economic growth in Jordan for the period (20102017). International Journal of Economics and Finance, 11(4), 114-118.

Asghar, N., Qureshi, S., \& Nadeem, M. (2015). Institutional quality and economic growth: Panel ARDL analysis for selected developing economies of Asia. A Research Journal of South Asian Studies, 30(2), 381404.

Assaf,A.A. (2014). The effect of Macroeconomic variables on Jordan's economic growth. European Journal of Social Sciences, 42(1), 101-111.

Ayuba, I., \& Mohd Khan, S. (2019). Domestic debt and economic growth in Nigeria: An ARDL bounds test approach. Economics and Business, 33, 50-68. 
Baharumshah, A. Z., Slesman, L., \& Wohar, M. E. (2016). Inflation, inflation uncertainty, and economic growth in emerging and developing countries: Panel data evidence. Economic Systems, 40(4), 638-657.

Barro, R. J. (1991). Economic growth in a crosssection of countries. The Quarterly Journal of Economics, 106(2), 407-443.

Barro, R. J. (1997). Determinants of economic growth: A cross-country empirical study. MIT Press.

Bass, A. (2019). Do institutional quality and oil prices matter for economic growth in Russia: An empirical study. International Journal of Energy Economics and Policy, 9(1), 76-83.

Bernard, A., \& Jones, C. (1996). Productivity and convergence across U.S. states and industries. Empirical Economics, 21(1), 113-135.

Brahim, M., \& Rachdi, H. (2014). Foreign direct investments, institutions and economic growth: Evidence from the MENA region. Journal of Reviews on Global Economics, 3, 328-339.

Central Bank of Jordan. (2010). Annual report, pp. 1-187.

Dal Bo, E., \& Rossi, M. A. (2007). Corruption and inefficiency: Theory and evidence from electric utilities. Journal of Public Economics, 91, 939-962.

Doan, H. Q. (2019). Trade, institutional quality, and income: Empirical evidence for SubSaharan Africa. Economies, 7(48), 1-23.

Epaphra, M., \& Massawe, J. (2016). Investment and economic growth: An empirical analysis for Tanzania. Turkish Economic Review, 3(4), 578-609.

Farhadi, M., Islam, M. R., \& Moslehi, S. (2015). Economic freedom and productivity growth in resource-rich economies. World Development, 72, 109-126.

Fenira, M. (2015). Trade openness and growth in developing countries: An analysis of the relationship after comparing trade indicators. Asian Economic and Financial Review, 5, 468-482.

Fischer, S. (1993). The role of macroeconomic factors in growth. Journal of Monetary Economics, 32(3), 485-512.

Hadhek, Z., \& Mrad, F. (2015). Trade openness, institutions, and economic growth. European Journal of Economics, Finance and Administrative Sciences, 72, 96-104.

Hall, R. E., \& Jones, C. I. (1999). Why do some countries produce so much more output per worker than others? The Quarterly Journal of Economics, 114(1), 83-116.

International Monetary Fund. (2005). Jordanian economic outlook. Working Paper No. 7/49.

Kacho, A. A., \& Dahmardeh, N. (2017). The effects of financial development and institutional quality on economic growth with the dynamic panel data generalized moment method: Evidence from the organization for economic cooperation and development countries. International Journal of Economics and Financial Issues, 7(3), 461-467.

Karimi, M., \& Daiari, E. H. (2018). Does institution matter for economic development? Evidence for ASEAN selected countries. Iranian Economic Review, 22(1), 1-20.

Keho, Y. (2017). The impact of trade openness on economic growth: The case of Cote d'lvoire. Cogent Economics \& Finance, 5(1), 1-14.

Keynes, J. M. (1936). The general theory of employment, interest and money. New York: Harcourt, Brace \& Co.

Knack, S., \& Keefer, P. (1995). Institutions and economic growth performance: Crosscountry test using alternative institutional measures. Economics and Politics, 7(3), 207-227.

Law, S. H., \& Bany-Ariffin, A. N. (2008). Institutional infrastructure and economic 
growth performance: Dynamic panel data evidence. Transition Studies Review, 15, 542-557.

Liu, J., Tang, J., Zhou, B., \& Liang, Z. (2018). The effects of governance quality on economic growth: based on China's provincial panel data. Economies, 6(56), 1-23.

Lucas, R. E. (1988). On the mechanics of economic development. Journal of Monetary Economics, 22(1), 3-42.

Maadia, H. H., Waqar, A., \& Hashmi, A. (2012). Role of investment in the course of economic growth in Pakistan. International Journal of Academic Research in Economic and Management Sciences, 1(5), 48-61.

Mansoor, A. M., \& Quillin, B. (2006). Migration and remittances: Eastern Europe and the former Soviet Union. World Bank Publications.

Mauro, P. (1995). Corruption and growth. The Quarterly Journal of Economics, 110(3), 681-712.

Nawaz, S., Iqbal, N., \& Khan, M. A. (2014). The impact of institutional quality on economic growth: Panel evidence. The Pakistan Development Review, 53(1), 15-31.

North, D. C. (1991). Institutions, institutional change, and economic performance. Cambridge, New York: Cambridge University Press.

Obeid, R., \& Awad, B. (2018). The effect of trade openness on economic growth in Jordan: An analytical investigation (19922015). International Journal of Economics and Financial, 8(2), 219-226.

Odhiambo, N. M. (2012). Inflation dynamic and economic growth in Tanzania: A multivariate time series model. Journal of Applied Business Research, 28(3), 317-324.

Odularu, G. O., \& Okonkwo, C. (2009). Does energy consumption contribute to economic growth performance? Empirical evidence from Nigeria. Journal of Economics and Business, 12(2), 43-79.
Ologunla, S. E., Kareem, R. O., \& Raheem, K. A. (2014). Institutions and the resource curse in Nigeria. Journal of Sustainable Development Studies, 7(1), 36-51.

Oyinlola, M. A., \& Akinnibosun, O. (2013). Public expenditure and economic growth nexus: Further evidence from Nigeria. Journal of Economics and International Finance, 5(4), 146-154.

Pesaran, H., Shin, Y., \& Smith, R. (2001). Bounds testing approaches to the analysis of levels of relationships. Journal of Applied Econometrics, 16(3), 289-326.

Phillips, A. W. (1958). The relationship between unemployment and the rate of change of money wage rates in the United Kingdom 1861-1957. Economica, 20(100), 283-299.

Romer, P. M. (1986). Increasing returns and long-run growth. Journal of Political Economy, 94(5), 1002-1037.

Romer, P. M. (1990). Endogenous technical change. Journal of Political Economy, 98(1), 71-102.

Roy, S., \& Roy, S. (2016). Foreign direct investment, institution and economic growth: Evidence from MENA region. Journal of Economics and Development Studies, 4(1), 39-49.

Sallam, M. A. M. (2016). Factors promoting economic growth in Egypt: Evidence from ARDL approach. Journal of Business and Economics, 7(11), 1842-1852.

Siyakiya, P. (2017). The impact of institutional quality on economic performance: An empirical study of European union 28 and prospective member countries. World Journal of Applied Economics, 3(2), 3-24.

Valeriani, E., \& Peluso, S. (2011). The impact of institutional quality on economic growth and developments: Empirical evidence. Journal of Knowledge Management, Economics and Information Technology, 6, $1-25$. 
Yildirim, A., \& Gökalp, M. F. (2016). Institutions and economic performance: A review of the developing countries. Procedia Economics and Finance, 38, 347-359.
Zouhaier, H., \& Kefi, M. K. (2006). Institutions and economic growth. Asian Economic and Financial Review, 2(7), 795-812.

Appendix A: Definitions of variables and source of data

\begin{tabular}{|c|c|c|c|}
\hline Variable & Label & Definition & Source \\
\hline GROWTH & $\begin{array}{l}\text { GPD per capita growth } \\
\text { rate }\end{array}$ & $\begin{array}{l}\text { The annual growth rate of gross domestic product per } \\
\text { capita. }\end{array}$ & WDI \\
\hline GFCF & $\begin{array}{l}\text { Gross fixed capital } \\
\text { formation }\end{array}$ & $\begin{array}{l}\text { Total gross fixed capital formation (land, machinery, } \\
\text { equipment purchase, construction works), as \% of } \\
\text { GDP }\end{array}$ & WDI \\
\hline GE & $\begin{array}{l}\text { Government } \\
\text { expenditure }\end{array}$ & $\begin{array}{l}\text { Total government current expenditure on purchasing } \\
\text { services and goods, as a share of GDP. }\end{array}$ & WDI \\
\hline INF & Inflation rate & Annual change rate in consumer price index $\%$. & WDI \\
\hline TO & Trade openness & The total value of exports plus imports, as $\%$ of GDP. & WDI \\
\hline INS & Institution index & Elements of governance and institutional quality. & WGI \\
\hline
\end{tabular}

Appendix B: Descriptive statistics

\begin{tabular}{lccccc}
\hline \multicolumn{1}{c}{ Variable } & Observations & Mean & Std. Dev. & Minimum & Maximum \\
\hline GROWTH & 22 & 0.89 & 2.65 & -2.88 & 5.72 \\
GFCF & 22 & 23.34 & 3.96 & 17.77 & 30.63 \\
GX & 22 & 20.09 & 3.35 & 15.49 & 25.55 \\
INF & 22 & 3.32 & 3.19 & -0.88 & 13.97 \\
TO & 22 & 118.59 & 16.66 & 90.05 & 147.5 \\
INS & 22 & 51.24 & 2.42 & 47.41 & 55.73 \\
\hline
\end{tabular}

Appendix C: Correlation matrix

\begin{tabular}{|c|c|c|c|c|c|c|}
\hline Variable & GROWTH & GFCF & GE & INF & TO & INS \\
\hline GROWTH & 1 & & & & & \\
\hline GFCF & 0.20 & 1 & & & & \\
\hline GX & 0.48 & 0.18 & 1 & & & \\
\hline INF & -0.06 & 0.49 & -0.13 & 1 & & \\
\hline TO & 0.48 & 0.79 & 0.18 & 0.65 & 1 & \\
\hline INS & 0.40 & 0.28 & 0.76 & -0.04 & 0.14 & 1 \\
\hline
\end{tabular}

